\title{
Waste and Accurate Management of Raw Material Inventory in Wood Companies
}

\author{
Emmy Ermawati \\ STIE Widya Gama Lumajang \\ Email: emmy.ermawati01@gmail.com
}

https://doi.org/10.30741/wiga.v10i1.517

A R T I C LE INFO

Date of entry:

13 January 2020

Revision Date:

15 February 2020

Date Received:

18 March 2020

\begin{abstract}
A B S T R A C T
Data obtained from the statistical office shows that Lumajang Regency, in general, is one of the largest albasia wood producers in East Java Province. Albasia wood is basically easily cultivated and minimal maintenance and is able to grow well even though the land is categorized as infertile. This is what makes people more interested in growing Albasia wood. The research objective is to analyze the optimal albasia wood raw material volume needed, to analyze the total cost of supplies, to analyze when a reorder point for albasia wood raw material is carried out, to analyze the amount of albasia wood safety stock that must be provided. Direct observation and observation activities in the field as well as taking documentation, interviews and discussions with CV. JAZINDO employees. Data Analysis Data analysis was done in a descriptive qualitative manner by recording to describe the state of the object under study based on facts and conditions that occurred in the field. Based on the results of data collection, calculation and analysis of data in $200 \mathrm{~cm}$ albasia wood are $945 \mathrm{~m} 3$, and for $260 \mathrm{~cm}$ albasia wood is $72 \mathrm{~m} 3$. Purchase of raw materials needs to be done after the inventory reaches the ROP limit. Safety stock calculation, obtained safety supplies for each type of albasia wood, namely $1543 \mathrm{~m} 3$ for albasia $100 \mathrm{~cm}$ wood, $548 \mathrm{~m} 3$ for albasia $130 \mathrm{~cm}$ wood, $848 \mathrm{~m} 3$ for albasia wood $200 \mathrm{~cm}$, and $56 \mathrm{~m} 3$ for albasia wood $260 \mathrm{~cm}$. With the EOQ method, it is recommended to order wood at calculated intervals.
\end{abstract}

Keyword: Economic Order Quantity, Material Requirements Planning, Just In Time, Waste Management

\section{INTRODUCTION}

Lumajang contributions from wood products are very large. Data obtained from the statistical office shows that Lumajang Regency, in general, is one of the largest albasia wood producers in East Java Province. This can be seen from the large number of albasia wood plants which are being developed by the community. Timber species that are not classified as hardwood are very easy to develop and can grow anywhere, even in unproductive fields or fields. From the data obtained from the Lumajang District Forestry Service, it can be seen that not a few Albasia wood processing companies have sprung up in Lumajang Regency, both large, medium and small companies. With the emergence of several Albasia wood processing companies in Lumajang Regency, it has increasingly encouraged the community, especially farmers, to plant their land 
with Albasia wood. The current research focus is on the supply of raw materials that must be prepared by timber entrepreneurs in Lumajang district using the Economic Order Quantity (EOQ) method.

Keep in mind Inventory is an inventory of assets owned by a company to be sold in normal business operations or goods that will be used or consumed in making goods to be sold. All operating supplies produce goods or products must have inventory. This is not only considered as an expense (liability) which is often also considered waste (waste), but it can also be said assets or assets owned by the company that will be disbursed in cash after the goods are sold.

The inventory management system is the policy of the company to determine the amount of inventory that must be set in a stable or normal position. If the amount of inventory is too much (overstock), the impact is that the funds or financial that are not used in large quantities will also be at risk of damage to goods or inventory and storage costs are very large. A lack of inventory will result in a lack of inventory (stockout). Not a few goods that are imported quickly and with a fairly large amount of needs. If this happens, the production process will be hampered and even stopped, resulting in many customers ordering to other companies.

Costs The development of science and technology that drives development in all fields, especially in the industrial sector, has various impacts, both positive and negative for the community. The positive impacts of industrial sector development enjoyed by the community include: increasing per capita income and living standards of the community, increasing the quality of public education, increasing health awareness and many more positive aspects of development. Indonesia is a country that is very rich in natural resources. So it is not surprising that Indonesia is wellknown as an exporter of various kinds of raw materials such as wood as raw material for furniture making, construction materials and industrial supplementary materials such as fruit boxes and other equipment. However, this can have a significant impact on the scope of the industry. The impact is quite felt around the manufacturing industry and home industry, namely the increasing economy of the Indonesian people in general and the Lumajang district community in particular.

The negative impact is the occurrence of environmental damage due to environmental pollution. Pollution of the environment will cause disruption to environmental sustainability that can endanger humans and other living creatures. With the various types of damage that occur in the environment, it takes real action to respond to the various types of damage. One of the people's awareness in responding to environmental changes is manifested in the selection and use of environmentally friendly products. The research results of Waskito and Harsono (2011) found that the level of public awareness began to grow on environmentally friendly products. This requires businesses to apply the concept of caring for the environment in their business processes, including their supply chains, so that the environment becomes a very important factor for the company.

Economic entities make the preservation of nature the basis for not only maintaining the sustainability of raw materials and energy but actually preserving the planet Earth as the only place for human life. Sustainable raw materials and energy will guarantee the long-term sustainability of economic entities while making the earth a comfortable and beautiful place to live. Not only pay attention to raw materials and energy, but pollution and waste generated by companies should be environmentally friendly and have very little impact on the environment. When humans are empowered, and the planet remains sustainable, profits or profits will come naturally, both benefits enjoyed by management as an agent managing the entity and investors as owners of the economic entity. So, profit or profit is not the first and foremost goal, but rather the impact of good and responsible company performance. Benefits that will be long term and sustainable (going concern).

Therefore proper and environmentally-friendly management is very important for us to think about. The work stages must be adjusted to proper standards. Proper is an assessment of a company's environmental management performance that requires measurable indicators. This is 
implemented by the Ministry of Environment of the Republic of Indonesia with the aim of increasing the role of companies in managing the environment while creating a stimulant effect in fulfilling environmental regulations and adding value to the preservation of natural resources, energy conservation, and community development. The waste produced by the company is not only as a residual product that is thrown away, but which is of value and must be environmentally friendly. A high level of pollution needs care from entrepreneurs whose production is certain to produce waste.

\section{RESEARCH METHOD}

This type of research is a qualitative study that examines participant perspectives with strategies that are interactive and flexible. Qualitative research is aimed at understanding social phenomena from the point of view of participants. Thus the meaning or understanding of qualitative research is research used to examine the condition of the object. It is natural that researchers are key instruments (Sugiyono, 2005). Examining supply chain performance effectively. A study must have an object of research so as to make the course of the study more focused on the goals that have been determined. Basically, the object is something that would or would be examined in research activity. According to Husen Umar (2005: 303), the object of research is an object that explains about what data or who is the object of research, also where and when the research was carried out, can also be added with other things if deemed necessary. Meanwhile, according to Sugiyono (2009: 38), the object of research is defined as an attribute or nature or value of people, objects or activities that have certain variations determined by researchers to be studied and then conclusions drawn. This conclusion is the aim of this study. The object of focus in this study is.

Data collection in this study was carried out with several techniques, including a. Observation. Observation is a technique or approach to get primary data by directly observing the data object (Jogiyanto, 2007: 89). In this study, researchers used non-behavioural observations with analysis of records (record analysis) in the form of data collection both current data records or historical data records. b. Interview. The interview is a two-way communication to get data from respondents. Researchers hold direct questioning both formally and informally with the parties involved in the issues to be discussed in research writing, namely regarding the application of accounting in the company's financial records. c. Literature review. A literature study is by going to the library and looking for literature books that fit the problem raised, and the information obtained will then be used to solve the problem.

Data Collection Methods In data collection activities, in conducting observations and in-depth interviews, qualitative researchers are highly required to explore and track as much as possible the reality of the phenomenon being studied (Faisal, 2001: 71). Thus in qualitative research, the goal to be achieved is to describe the situation or phenomenon that is happening. Therefore the instrument is needed because researchers are required to be able to find data raised from certain phenomena or events. Dealing with that, the researchers collected data through direct observation and observation activities in the field while taking documentation, interviews and discussions with employees of CV.JAZINDO. Data Analysis Data analysis was carried out in a qualitative descriptive manner by recording to describe the condition of the object under study based on facts and conditions that occurred in the field. The following is the mapping of the supply chain data in the form of suppliers, producers and consumers. Also identified various problems that arise in the supply chain. Next, an analysis of supply chain management is carried out which finally realizes that the success of a company is highly dependent on the coordination, integration and management of important business processes of various supply chain members.

The focus of this research is 1 . The volume of raw material requirements ( $\mathrm{m}^{3} / 3$ months). 2. Costs for ordering raw materials $\left(\mathrm{Rp} / \mathrm{m}^{3}\right)$ are costs incurred in connection with ordering raw materials, including a. Telephone charges, b. Transportation and demolition costs, c. Administrative costs, 3. 
Storage costs $\left(\mathrm{Rp} / \mathrm{m}^{3}\right)$ are costs incurred in connection with the storage of raw materials, including a. Maintenance cost, b. Damage fee, 4. Waiting time in units of days is the length of time between starting ordering raw materials until the arrival of ordered raw materials is received in inventory warehouse.

Data analysis methods used in this study are 1. Economic Order Quantity. This model identifies the optimal order or purchase quantity with the aim of minimizing inventory costs consisting of ordering costs and storage costs. Handoko, 2000 stated that the EOQ (Economic Order Quantity) method is by having a permanent need, to find out the number of economic order purchases. The EOQ calculation is as follows: $E O Q=\sqrt{\frac{25 D}{H}}$. EOQ $=$ Optimal purchase quantity $\left(\mathrm{m}^{3}\right) . \mathrm{D}=$ Usage Quantity per period $\left(\mathrm{m}^{3} /\right.$ year). $\mathrm{S}=$ Cost per order $\left(\mathrm{Rp} / \mathrm{m}^{3}\right) . \mathrm{H} \quad=$ Cost of storage per unit per period (Rp / $\mathrm{m}^{3} /$ year). 2. Safety Stock. Asrori (2010) states that the determination of the amount of safety stock can be done by comparing the use of raw materials and then looking for the standard deviation, with the following formula: Standard Deviation $\alpha=\sqrt{\sum\left(\frac{x-x)^{2}}{n}\right.}$. n: The number of raw material ordering periods. X: Amount of actual use of raw materials per period $\left(\mathrm{m}^{3}\right.$ / year). -: Average use of raw materials $\left(\mathrm{m}^{3}\right)$. To find out how much safety stock (safety stock) used the following formula: Safety Stock $=\mathrm{Sd}$ x Z. Sd = Standard Deviation. Z = The safety factor is formed on the basis of the company's ability. 3. Reorder Points. Reorder point is when or at a certain time the company has to reorder goods so that the arrival of the order is exactly the end of the basic materials purchased, especially with the EOQ method (Gitosudarmo, 2002 in Ruauw, 2011). The ROP calculation is as follows: ROP = Safety Stock + (Lead Time $x$ Q). ROP $=$ Reorder point. Lead time $=$ Waiting time (days). Safety stock $=$ Safety stock $\left(\mathrm{m}^{3}\right)$. Q = Average raw material usage per day ( $\mathrm{m}^{3} /$ day). 4. Calculation of Total Cost of Raw Material Inventory (TIC). To find out the total minimum inventory cost of raw materials required by the company by using the EOQ calculation. The TIC calculation is as follows: ROP = Penggunaan average material/day $\mathrm{x}$ lead time x safety stock. $\mathrm{D}=$ Quantity $\left(\mathrm{m}^{3} /\right.$ year). Usage per period. $\mathrm{S}=$ Cost per order $(\mathrm{Rp} /$ year). $\mathrm{H}=$ Storage cost per unit $\left(\mathrm{Rp} / \mathrm{m}^{3} /\right.$ year $) .5$. Maximum Inventory. Maximum inventory is needed by the company so that the quantity of inventory in the warehouse is not excessive, so there is no waste of working capital (Rumincap, 2010). As for knowing the maximum inventory size, the formula can be used: Maximum Inventory $=$ Safety Stock + EOQ. Safety Stock $=$ Safety stock. EOQ = Optimal purchase quantity

\section{RESULTS AND DISCUSSION}

According to an interview with the leadership of CV.JAZINDO is a company engaged in wood processing in Lumajang district. The raw material used is a log, while the production is in the form of wood sheets which will be processed again into plywood raw materials that are sent locally in Lumajang regency or outside Lumajang. CV.JAZINDO procures wood raw materials by ordering twice a month from suppliers in the Lumajang area who have already made work contracts. According to Ekasari (2015), Data obtained from the company regarding 2017 raw material requirements data were selected in accordance with the assumptions of the application of the Economic Order Quantity (EOQ) method, namely: 1. Only one item of the item (product) counts. 2. The purchase price of materials per boarding unit. 3 . Required materials are always available in the market whenever needed. 4. Lead time is constant. 5. Every order is received in one shipment and can be used immediately. 6. There are only three types of costs, namely: the price of goods, storage costs, and the cost of ordering. a. Storage Costs Costs to store an item in inventory for a certain period of time, usually one year. Related to physical ownership in storage (Heizer and Render, 2015: 187). Based on observations at CV.JAZINDO the costs include electricity costs, warehouse labour costs, equipment repair costs, PBB (land and building tax). b. Booking Fees 
Fees for relating to ordering raw materials. Costs here vary with the actual order placement (Heizer and Render, 2015: 187).

Table 1. Calculation Summary

\begin{tabular}{ccccc}
\hline Information & $\mathbf{1 0 0} \mathbf{~ c m}$ & $\mathbf{1 3 0} \mathbf{~ c m}$ & $\mathbf{2 0 0} \mathbf{~ c m}$ & $\mathbf{2 6 0} \mathbf{~ c m}$ \\
\hline $\mathrm{Q}^{*}$ & $1568 \mathrm{~m} 3$ & $425 \mathrm{~m} 3$ & $1045 \mathrm{~m} 3$ & $82 \mathrm{~m} 3$ \\
$\mathrm{~N}$ & 53 time & 30 time & 41 time & 26 time \\
$\mathrm{T}$ & $7 \mathrm{time}$ & 15 day & 10 day & 18 day \\
rop & $1679 \mathrm{~m} 3$ & $652 \mathrm{~m} 3$ & $965 \mathrm{~m} 3$ & $67 \mathrm{~m} 3$ \\
$\mathrm{Ss}$ & $1643 \mathrm{~m} 3$ & $648 \mathrm{~m} 3$ & $948 \mathrm{~m} 3$ & $66 \mathrm{~m} 3$ \\
$\mathrm{TC}$ & $\mathrm{Rp} 474.747 .315 .33$ & $\mathrm{Rp} 25.209 .189 .72$ & $\mathrm{Rp} 183.057 .449 .6$ & $\mathrm{Rp} 3.773 .031 .23$
\end{tabular}

Source: Data processed (2020)

In the EOQ calculation above, it is known that the lead time of the order is 2 days, meaning that raw material orders will arrive after 2 days the order is made. Whereas the optimal Q for $100 \mathrm{~cm}$ sengon wood is $1468 \mathrm{~m} 3$, the optimal Q for sengon wood $130 \mathrm{~cm}$ is $325 \mathrm{~m} 3$, the optimal Q for 200 $\mathrm{cm}$ sengon wood is $945 \mathrm{~m} 3$ and the optimal Q for $260 \mathrm{~cm}$ sengon wood is $72 \mathrm{~m} 3$. The amount above illustrates the large orders that must be carried out by the company every time they order raw materials. For ordering frequency $(\mathrm{N})$ for each type of sengon wood is $100 \mathrm{~cm} 43$ times, $130 \mathrm{~cm} 20$ times, $200 \mathrm{~cm} 31$ times, and $260 \mathrm{~cm} 16$ times. The numbers above illustrate the number of companies carrying out orders to suppliers within a certain period where in this case is 1 year. Based on these calculations, this frequency is the ideal frequency to minimize overall costs. While the results of the calculation of the time interval (T) for each type of sengon wood is $100 \mathrm{~cm}$ for 7 days, $130 \mathrm{~cm}$ for 15 days, $200 \mathrm{~cm}$ for 10 days and $260 \mathrm{~cm}$ for 18 days. The figures above illustrate the time span between ordering one to the next so that it is expected that there will be no buildup of raw materials at the factory and there will be no shortage of supplies during the waiting period.

Reorder Point Analysis as shown in the ROP point table for albasia $100 \mathrm{~cm}$ wood is $1579 \mathrm{~m} 3$, $130 \mathrm{~cm}$ is $552 \mathrm{~m} 3,200 \mathrm{~cm}$ is $865 \mathrm{~m} 3$, and $260 \mathrm{~cm}$ is $57 \mathrm{~m} 3$. ROP illustrates if the inventory in the company has reached these numbers, a reorder should be carried out for $\mathrm{Q} *$. Thus raw materials will be received along with the depletion of inventory in the company so that it does not cause a buildup of raw materials and also no shortage of raw materials during the waiting time for shipping wood to the warehouse-Safety Cost Analysis From the calculations in the EOQ calculation table. Previously, safety stock values for each type of sengon wood were produced. Safety stock for $100 \mathrm{~cm}$ sengon wood is $1543 \mathrm{~m}, 130 \mathrm{~cm}$ is $548 \mathrm{~m}, 200 \mathrm{~cm}$ is $848 \mathrm{~m}$, and $260 \mathrm{~cm}$ is $56 \mathrm{~m} 3$. This safety stock is useful to anticipate inventory shortages during the lead time due to unpredictable things such as increased demand. In addition, safety stock can also be used as anticipation of rising raw material prices. Total Cost Analysis Based on the results of the comparison of the total cost of inventory from the actual method and the EOQ method, it can be seen that using the EOQ method saves more overall costs. The calculation is obtained from costs costs such as ordering costs in the form of shipping costs, and saving costs in the form of labour costs and costs of receiving raw materials in the warehouse. The most significant cost savings are $100 \mathrm{~cm}$ albasia because this type of wood is the most widely used in the production process. For optimal Q it also differs rather large where $Q^{*}$ for $100 \mathrm{~cm}$ wood is $1468 \mathrm{~m} 3$ while the average company order is $4608 \mathrm{~m} 3$. This EOQ method saves Rp. 345,757,789,375 for $100 \mathrm{~cm}$ wood species. By using the EOQ method it was found that there was a cost efficiency of $42 \%$. The overall cost savings can also be seen in other types of sengon wood. For $130 \mathrm{~cm}$ sengon wood, cost efficiency of $10 \%$ was found. For $200 \mathrm{~cm}$ albasia wood, there is a cost-efficiency of $32 \%$. Whereas for $260 \mathrm{~cm}$ sengon wood there is a cost efficiency of $4 \%$. When compared with the company's actual methods, using this probabilistic EOQ method will greatly save total inventory costs. 
Waste treatment, or domestic wastewater treatment, is the process of removing contaminants from wastewater and household waste, both runoff (effluent) and domestic. This includes physical, chemical and biological processes to eliminate physical, chemical and biological contaminants. The aim is to produce a stream of sewage (or treated effluent) and solid waste or sludge suitable for disposal or reuse of the environment. This material is often accidentally contaminated with many toxic organic and inorganic compounds. The definition of wood waste is wood that is leftover in various shapes and sizes that must be sacrificed in the production process because it cannot produce high-value products from an economic perspective with a certain level of processing technology used (DEPTAN, 1970). Sunarso and Simarmata (1980) in Iriawan (1993) explained that wood waste is the remnants of wood or parts of the wood that are considered no longer economic value in a particular process, at certain times and certain places that may still be utilized in different processes and times.

Based on the origin of wood waste can be classified as follows: Wood waste originating from land clearing areas for agriculture and plantations includes unburned wood, roots, stumps, branches and twigs. Wood waste originating from logging areas in HPH and IPK areas includes pieces of wood of various shapes and sizes, stumps, bark, small diameter tree branches and crowns from felled trees. Waste produced from plywood and sawmills in the form of sawdust, cutting edge, sanding powder, log end (wood heart) and veneer (plywood sheet). Simarmata and Haryono (1986) in Iriawan (1993) stated that wood waste could be divided into 2 groups, namely: (a) Wood waste that occurs in forest exploitation activities in the form of felled trees consists of stems to free branches, stumps and parts above the first branch. (b) wood waste originating from the wood processing industry, among others, in the form of broken veneer sheets, log end or unused quality wood, peeled scraps, pieces of logs, pieces of veneer sheets, sawdust, sanding powder, sanding, cuttings from sawn wood and skin. Sumadiwangsa and Widarmana (1982) state that the types of wood waste that occur in the plywood industry include log end $\log$ core, veneer peel, damaged veneer, the remaining piece of plywood edge, sawdust and sanding powder. Meanwhile, Rachman and Suparman (1978) in Iriawan (1993) stated that wood waste in the sawing industry consists of sawdust, slabs and tip cuts.

Wood waste, especially from the plywood industry, has been used as a blockboard, particleboard and as a fuel for heating boilers and wood charcoal while the use of waste from the plywood industry in our area is not yet optimal. Some of which can be developed for the utilization of plywood industry waste, among others. For handicraft materials in the form of woven walls and ceilings, as well as the use of pieces of flakes that can be used as salted fish boxes and egg boxes and boxes for ketchup bottles or sauces. Laminated wood materials for the manufacture of pallet bearings, furniture and birdcage manufacture. Regarding the calculation and implementation in accordance with the requirements of PKKI 1961 article 12 sub 4 and article 18 which are called compound layered constructions are wooden constructions whose fibres are parallel to each other, so that they are large blocks, thick $25-50 \mathrm{~mm}$ thin boards. Layered construction with adhesive. What is meant by the term adhesive and the use of wood adhesives for the manufacture of compound-coated construction with adhesives (according to Heinz Frick) is wood construction that uses thin boards that are glued together with fibres parallel to the adhesive, so it is a largesized block.

Plywood Industry Waste Management System. Solid Waste (powder and bark). This plywood production process produces a lot of waste, especially wood waste itself because it is a staple of production. The waste is produced from the process of cutting, grinding and stripping the wood. Waste wood in the form of powder and bark can be maximized again for the use of fuel in the boiler. Because all this time the powder and bark are only used for household fuel or only made as rubbing ash. By re-utilizing the waste for combustion process fuel in the boiler, it will be able to reduce the amount of waste produced and can minimize the cost of boiler fuel whereas untapped wood and powder waste can be used to make furniture for household appliances. So it will be economically valuable and environmentally friendly - solid Waste (Glue). Solid waste from the 
plywood production process is produced from sticky glue on the production machine. The highest glue on the machine will certainly disrupt the productivity of the machine. The chemical content contained in the glue is phenol. Because the material is volatile into the air and smells, then it needs to be processed so as not to become an environmental polluter. One of the technologies that can be used for this waste is an incinerator because it can burn this waste completely and produce fly ash. Incinerator combustion uses very high temperature and a certain time for each type of waste - solid Waste (Product Fail). The results of damaged wood production will certainly become a new waste to the environment if not done carefully before disposal. The damaged production waste can actually be used as fuel for the combustion process in Boyler because of the high-calorie content of the wood. Liquid waste. In addition to producing solid waste, the wood production process also produces liquid waste. This liquid waste is produced from the process of washing wood, pressing, etc. The liquid waste can be reprocessed so that when discharged into the river or the environment. Therefore it is necessary to do various analyzes in advance of the waste produced. The analysis is needed to determine the characteristics of waste as well as the right technology for processing the waste. One of the wastewater treatment systems is the WWTP Treatment System (Wastewater Treatment Plant). The processing system aims to eliminate the content of suspended solids, colloids, organic and inorganic materials, as well as chemical contents resulting from the plywood production process.

The kinds of waste produced from the washing process are tannins, wood chips, sawdust, wet and dry vine waste, peeled bark, and soil, sand and mud from logging in the forest that is brought to the factory industry. After knowing the characteristics and types of waste generated from this production, the next process can be carried out, namely processing at WWTP. The initial process at the level of waste treatment is Pretreatment, then Primary Treatment, then Secondary Treatment, and finally Tertiary Treatment. While the liquid waste treatment system is based on its operating unit, the processing is carried out by means of physics, chemistry, biology, and a combination of the three. The physical processing begins with the Screening process; this process aims to separate pieces of wood and so on to make it easier for the next WWTP process.

Then the next process is the Grit Chamber process, in this process, soil, gravel, sand and other particles that can settle in the channel and pipes are removed so that it can protect pumps and other equipment from clogging, abrasion, and overloading. Then the next process carried out is Equalization, this process aims to homogenize the wastewater solution, equalize the flow rate and characteristics of the wastewater, reduce the size and cost of subsequent processing processes, and improve the performance of subsequent processes. Then after equalization, the sedimentation process is carried out. This process is to obtain clear wastewater and can facilitate the handling of sludge. After a series of physical processes, proceed with the processing of chemical processing systems.

In the chemical processing, the first treatment is neutralization. This process aims to regulate the $\mathrm{pH}$ conditions in wastewater to be in neutral conditions because if it is too acidic or alkaline, the water will be toxic. The waste produced in this production process is acidic. Therefore it is necessary to add a solution of $\mathrm{NaOH}$ so that the $\mathrm{pH}$ becomes neutral. Then after neutralization, continued with precipitation. This process aims to reduce materials that can cause sediment formation and eliminate heavy metal content that may be present in this wastewater by adding AL2 (OH) CL4 (PAC), Soda Ash (Caustic Soda), Flocculant (PAM) and AL2 SO4. After the precipitation process (chemistry), proceed with the biological treatment process.

Biological treatment, one of which is by Aeration, this process aims to eliminate pollutants by using microorganisms (bacteria) or contacting waste with oxygen (aerator). The next process is ozonation; this process is done by adding $\mathrm{O} 3$ to the water. This process aims to oxidize heavy metals, increase flocculation, bleach ingredients, destroy mould and mildew, destroy and reduce larvae. The next processing process is the Sedimentation process, which uses gravity to separate particles and microorganisms after the aeration and ozonation process from water. In the process 
of sedimentation, only particles heavier than water can be separated, such as gravel, sand, and mud. The final stage is checking various test parameters, namely BOD, DO, COD, PH, TSS, PHENOL in the Control Tub, in this section also used observational indicators namely with carp and water hyacinth. Both indicators are sensitive to wastewater, so that water quality can be known to animals and plants. If the indicator or test media dies, the treated water is still dangerous and needs to be reprocessed. Meanwhile, if the indicator can live within a specified time, then it is certain that the water can already be discharged environment (outlet).

Plywood Industry Non-Specific Waste. Waste from cotton cloth produced from the production process can be used for boiler fuel. Then used oil storage drums can be cleaned and used for storing rainwater, or sold to a drum collecting agent for resale to the community. The results of washing drums containing used oil and used oil from the use of production machines and operational vehicles will become hazardous waste, so the waste can be said to be B3 waste because the oil content is still present. Another non-specific waste is medical waste from the treatment of directors or employees; the waste can be in the form of chemicals or syringes. Medicinal waste and syringe are infectious wastes whose handling needs special methods ranging from packaging the waste to storing it before it is processed. Then the waste generated by supporting production materials that have expired, e.g. adhesives and chemicals. If it is possible to be processed in an incinerator, the waste will be burned. However, if it is no longer possible to be processed again because it is too dangerous in its contents (B3), then the last alternative is landfill. This alternative is the final path of waste disposal after various types of treatment are no longer able to handle it. The landfill itself must be done properly and need intensive supervision for \pm 30 years. Waste to be landfilled must be properly considered starting from the conditions of the landfill and its maintenance so as not to cause problems later on.

Alternative Utilization. Understanding that waste generated from a production process has economic value is a new paradigm that is being developed at this time. Waste is not a matter that must be avoided or covered up in its management. Waste also has economic value. The 3R concept (Reuse, Recycle and Recovery) will encourage each waste producer to make the waste have economical value. Powder Charcoal and Charcoal Charcoal. Specifically for making charcoal from wood sawdust, the technology used is different from the way of making charcoal and coal kiln systems. The technology used in the process of making charcoal from wood sawdust is to use modified drums and equipped with air holes around the drum body and chimney in the middle of the drum body. The yield of sawdust charcoal produced in this way is $15-20 \%$. The bound carbon content of $50-72 \mathrm{cal} / \mathrm{g}$ and the heating value of charcoal between $5800-6300 \mathrm{cal} / \mathrm{g}$. Considering this method is less effective when viewed from the length of the process of making charcoal powder which requires more than 10 hours with not too many results, then new technologies are being made to overcome the shortcomings of the drum method. This technology is designed with a construction made of iron plate elbows that can be assembled (bolt system) and covered with zinc sheets which also use a bolt system. In one day ( 9 hours) can fabricate $150-200$ $\mathrm{kg}$ of powder which results in a charcoal yield of between $20-24 \%$. The moisture content of $3.49 \%$, ash content of $5.19 \%$, levels of flying matter $28.93 \%$ and carbon content of $65.88 \%$. Sawdust charcoal produced can be made or further processed into charcoal briquettes, activated charcoal, and as a medium for seedling plants. The cost to make this semi-continuous kiln is Rp. 2000,000. Charcoal for waste and cut ends can be made using a dome furnace made of brick which is plastered with clay and equipped with a reservoir or cools the smoke coming out of the chimney so as to obtain tar and distillate liquids that can be applied further. In Thailand, this wood vinegar liquid is the main product in terms of making charcoal which was previously a by-product because the selling price is high at 50 Bath / L while for charcoal it only costs $4 \mathrm{Bath} / \mathrm{kg}$. From a furnace capacity of 4.5 tons, a distillation liquid of 150 litres and $800 \mathrm{~kg}$ of charcoal are produced (Sujarwo, 2000). The results of a study conducted by Nurhayati (2000) showed that a furnace with a capacity of $445 \mathrm{~kg}$ produced $60.6 \mathrm{~kg}$ of charcoal and distillate liquid $75.5 \mathrm{~kg}$. The cost of making a brick stove plastered with clay equipped with a cooling process tool is Rp. 4000,000 (Nurhayati, 2000). 
Activated charcoal is charcoal that is further processed at high temperatures so that the pores are open and can be used as an adsorbent. The process used is mostly using a chemical method where the raw material is immersed in the solution, $\mathrm{CaCl} 2, \mathrm{MgCl} 2, \mathrm{ZnCl} 2$ and then heated by burning at a temperature of $5000 \mathrm{C}$. The results show that the quality of activated charcoal. In this case, the amount of absorption of iodine meets the SII standard because its absorption is more than $20 \%$. In accordance with technological developments and increasingly stringent standard requirements and environmental issues, this technology is not possible to be developed further, especially for the use of $\mathrm{ZnCl} 2$ activating agents which can release chlorine gas upon activation. Responding to the case above, the technology of making activated charcoal has been improved by oxidizing gases at high temperatures and a combination of chemical methods using $\mathrm{H} 3 \mathrm{PO} 4$ as an activating agent and gas oxidation. The results of Pari's research (1996) conclude that activated charcoal from chemically prepared sengon powder can be used to attract $\mathrm{Zn}, \mathrm{Fe}, \mathrm{Mn}, \mathrm{Cl}, \mathrm{PO} 4$ and SO 4 metals contained in contaminated well water and can also be used to purify industrial wastewater paper pulp (Pari, 1996). Activated charcoal activated with NH4HCO3 activating agent produces activated charcoal that meets Japanese Standards with iodine absorption of more than $1050 \mathrm{mg} / \mathrm{g}$, and the yield of activated charcoal is 38.5\% (Pari, 1999). In 1986 an active charcoal factory in Kalimantan was established which made activated charcoal from wood sawdust waste with a production capacity of 3000 tons/year. Until now, there are two active charcoal processing factories that use wood sawdust as the main raw material. The quality of activated charcoal produced meets SNI because the iodine absorption capacity is more than $750 \mathrm{mg} / \mathrm{g}$, but does not meet Japanese standards. The selling price of activated charcoal varies between IDR 6,500 - IDR 15,000/ $\mathrm{kg}$ depending on the desired quality. For activated charcoal made in Germany, the price reaches Rp 65,000 / $0.5 \mathrm{~kg}$.

Charcoal briquettes are charcoal that is further processed into briquettes (more attractive appearance and packaging) that can be used for daily energy needs. The making of charcoal briquettes from wood processing industry waste is done by adding tapioca adhesive, in which raw materials are made up first and then crushed, mixed with adhesives, printed (cold press) with a manual hydraulic system and then dried. Hartoyo, Ando and Roliadi (1978) conclude that the quality of charcoal briquettes produced is commensurate with English-made charcoal briquettes and meets the requirements applicable in Japan because they produce low levels of ash and volatile substances as well as high levels of bound carbon and calorific value. In addition, the results of Sudrajat's research (1983) that made charcoal briquettes from 8 types of wood with a mixture of starch and molasses adhesives concluded that the higher the specific gravity of the wood, the higher the charcoal briquette's height would be. The resulting density is between $0.45-1.03 \mathrm{~g} / \mathrm{cm} 3$ and the heating value is between $7290-7456 \mathrm{cal} / \mathrm{g}$. The making of charcoal briquettes which is done now is the raw material used is already directly in the form of charcoal powder so that the process of grinding and sifting of raw materials carried out previously can be removed. The next process is the addition of tapioca adhesives and pressing as the previous charcoal briquette making. To make a hydraulic briquette system briquette printing machine with 24 holes, it costs Rp. 18,000,000. In 1990 there was a charcoal briquette factory without adhesive in West Java and East Java that used sawdust as its main raw material. The process of making charcoal briquettes is different from the method mentioned above. The raw material for dried sawdust is then made of wood briquettes with a screw system running and running while heated and then fabricated in a brick kiln. The quality of the charcoal briquettes produced has a calorific value of less than 7000 $\mathrm{cal} / \mathrm{g}$ that is equal to $6341 \mathrm{cal} / \mathrm{g}$ and the bound carbon content of $74.35 \%$. However, studies conducted in West Java show that a charcoal briquette factory with a capacity of $260 \mathrm{~kg}$ of charcoal briquettes/day can be profitable. In supermarkets, charcoal briquettes from wood can be purchased at a selling price of $\mathrm{Rp} 12,000 / 2.5 \mathrm{~kg}$.

The type of waste used as an energy source can be in the form of cut ends, peeled debris, shavings and wood sawdust, all of which are used to heat a boiler. In the plywood industry, the use of fuel for boilers is $19.7 \%$ or $40 \%$ of the total waste produced. For the small scale industrial drying board, the drying process is carried out directly by burning the waste of a piece or tip piece, the heat produced with the help of a blower is channelled into a room containing the board to be dried. 
Nurhayati's research results (1991) concluded that to dry the sengon board as much as $10260 \mathrm{~kg}$ of wet weight at $161.04 \%$ water content to $5220 \mathrm{~kg}$ of boards at $6.58 \%$ moisture content for 6 days spent $3433 \mathrm{~kg}$ of waste. Another technology is the process of converting wood to fuel through the gasification process. Nurhayati and Hartoyo's (1992) research results concluded that camphor wood waste can be converted into fuel with a fluidized bed gasification system that produces a gas calorific value of $7.106 \mathrm{MJ} / \mathrm{m} 3$ with a gas composition $\mathrm{H} 2=5.6 \% ; \mathrm{CO}=11.77 \%, \mathrm{CH} 4=3.99 \%$; $\mathrm{C} 2 \mathrm{H} 4=4.34 \%, \mathrm{C} 2 \mathrm{H} 6=0.21 \%, \mathrm{~N} 2=57.69 \% \mathrm{O} 2=0.40 \%$ and $\mathrm{CO} 2=15.71 \%$.

The use of charcoal either from exploitation waste or from the wood processing industry for soil conditioning is one alternative to the use of charcoal as an energy source. Morphologically charcoal has an effective pore for binding and storing soil nutrients. Therefore the application of charcoal inland especially nutrient-poor soils can build and improve soil fertility, because it can improve several functions including air and groundwater circulation, soil $\mathrm{pH}$, stimulating the formation of endospores and ectomycorrhizae, and absorbing excess soil $\mathrm{CO} 2$. So as to increase the productivity of land and plantation forests. The results of preliminary research by Gusmailina et al. (1999), showed that the administration of bamboo charcoal and activated charcoal as a mixture of growing media could increase the percentage of growth both at the seedling and seedling level of Eucalyptus urophylla. Sawdust charcoal and sarasah charcoal can increase the growth of saplings of Acacia mangium and Eucalyptus citriodora by more than $30 \%$ compared without charcoal administration, as well as giving charcoal in the field can increase the stem diameter of E. urophylla plants. As for agricultural crops such as chilli (Capsicum annum), the addition of bamboo charcoal by $5 \%$ and husk charcoal by as much as $10 \%$ can increase the percentage of plant height growth to $11 \%$. However, it is better if, at the time of planting, the added charcoal is mixed with compost. Preliminary results showed that the addition of wood sawdust charcoal and powder compost resulted in a larger tree diameter $(7.9 \mathrm{~cm})$ than without compost.

Sawdust is one type of sawn wood processing industry waste. Alternative uses can be made into compost for plant fertilizer. Komarayati's research results (1996) show that composting of sawdust (Pinus merkusii) sawdust and rubberwood sawdust (Hevea braziliensis) using an EM4 activator and manure produced compost with a $\mathrm{C} / \mathrm{N}$ ratio of 19.94 and yield of $85 \%$ in time 4 months. In addition, Pasaribu (1987) also utilizes sengon sawdust (Paraserianthes falcataria) as raw material for compost. The compost produced has a C / $\mathrm{N}$ ratio of 46.91 with a yield of $90 \%$ within 35 days. The results of research on the provision of compost powder and rubber tree sarasah can increase the growth of Eucalyptus urophylla 40-50\% within 5 months compared without the provision of compost.

\section{CONCLUSION}

The conclusion in this study 1) Based on the results of data collection, calculation and analysis of data in $200 \mathrm{~cm}$ albasia wood is $945 \mathrm{~m} \mathrm{3}$, and for $260 \mathrm{~cm}$ albasia wood is $72 \mathrm{m3}$. 2) Purchasing raw materials needs to be done after the inventory reaches the ROP limit of $1579 \mathrm{~m} 3$ for albasia 100 $\mathrm{cm}$ wood, $552 \mathrm{~m} 3$ for albasia $130 \mathrm{~cm}$ wood, $865 \mathrm{~m} 3$ for albasia $200 \mathrm{~cm}$ wood and $57 \mathrm{~m} 3$ for albasia $260 \mathrm{~cm}$. The company needs to order when the inventory reaches ROP, not after the supply is running low. 3) Based on the calculation of safety stock, obtained safety supplies for each type of albasia wood are $1543 \mathrm{~m} 3$ for albasia $100 \mathrm{~cm}$ wood, $548 \mathrm{~m} 3$ for albasia $130 \mathrm{~cm}$ wood, $848 \mathrm{~m} 3$ for albasia $200 \mathrm{~cm}$ wood, and $56 \mathrm{~m} 3$ for albasia wood $260 \mathrm{~cm}$. These figures are expected to meet the needs of the company when unexpected things happen. 4) The frequency of messages for each type of Albasia wood is also different. So far, the company orders 12 times a month for all types of albasia wood per year. Using the EOQ method, it is recommended to order for $100 \mathrm{~cm}$ albasia wood 43 times with an order interval for 7 days, for albasia $130 \mathrm{~cm}$ wood 20 times with an order interval for 15 days, for albasia $200 \mathrm{~cm}$ wood 31 times with an order interval for 9 days, and for Albasia $260 \mathrm{~cm} 16$ times with an order interval of 18 days. Although the order costs generated are 
quite large, but the recommended EOQ method will save the company's overall costs. 5) The total cost of raw materials using the EOQ method for $100 \mathrm{~cm}$ albasia wood is IDR 474,747,315,335, while the company's total actual cost is IDR $820,505,104,710$, the total cost generated is $42 \%$ lower. For $130 \mathrm{~cm}$ albasia wood, the total cost using the EOQ method is Rp. 25,209,189,720, while the actual total cost is Rp. $27,918,962,173$, - the total cost produced is lower by $10 \%$. For $200 \mathrm{~cm}$ albasia wood, the total cost using the EOQ method is IDR 183,057,449,608, while the actual total cost is IDR 272,433,302,001, - the total cost produced is $32 \%$ lower. And for $260 \mathrm{~cm}$ albasia wood, the total cost using the EOQ method is Rp. 3,773,031,233, while the actual total cost is Rp. 3,947,048,699 - the total cost produced is lower by 4\%. Overall, using the EOQ method results in total cost savings for each type of albasia wood. 6) Waste management carried out at timber companies in Lumajang Regency is in accordance with the BLACK PROPER Standard. Black PROPER: is the lowest rank in managing the environment, Has not made efforts in environmental management as required so that it has the potential to pollute the environment, and is at risk of being closed down by KLH in the areas of Water Management Assessment, Land Damage Assessment, Marine Pollution Control, Management B3 waste, Air Pollution Control, Water Pollution Control, AMDAL Implementation.

According to the results of the analysis and discussion and observations that have been made, the researcher tries to give some suggestions as follows: 1 . CV. JAZINDO can do better inventory control by considering the cost efficiency factor by applying the Economic Order Quantity (EOQ) method. 2. The company needs to place an order as needed so as to minimize excessive savings. And the company should set a reorder point and not wait for the buffer stock to run low so that the production process is not chaotic during the grace period. 3. Companies should determine or use safety stock that has been calculated through cost and time considerations. This is necessary so that the company does not experience shortages of inventory during the lead time, which can disrupt the production process.

\section{REFERENCE}

Asrori. H. (2010). Analisis Pengendalian Persediaan Bahan Baku Kayu Sengon PT. Abhirama Kresna Dengan Metode EOQ. Skripsi. Program Studi Manajemen Industri Fakultas Ekonomi Universitas Sebelas Maret Surakarta.

Bank Indonesia. (2005). Pola Pembiayaan Usaha Kecil (PPUK) Furniture Kayu (Jurnal). Biro Pengembangan UMKM Direktorat Kredit, BPR dan UMKM Bank Indonesia. Jakarta.

Daryanto. (2012). Manajemen Produksi. PT Sarana Tutorial Nurani Sejahtera: Satu Nusa Studio.

Dinas Kehutanan Provinsi Sulawesi Utara. (2014). Profil Kehutanan Provinsi Sulawesi Utara $(P d f)$.

Fahmi. (2012). Manajemen Produksi dan Operasi. Penerbit: Alfabeta, Bandung.

Haming, M. dan Mahfud, N. (2012). Manajemen Produksi Modern (Operasi Manufaktur dan Jasa). Edisi Kedua Cetakan Pertama. Penerbit : PT Bumi Aksara. Jakarta.

Handoko. (2000). Dasar-dasar Manajemen Produksi dan Operasi. Penerbit: BPFE Yogyakarta.

Helena. (2005). Analisis Sistem Pengadaan dan Pengendalian Persediaan Bahan Baku Jamu Tradisional Pada PT.X Bogor. Program Studi Manajemen Agribisnis Fakultas Pertanian, Institut Pertanian Bogor.

Kinho, J. dan Mahfudz (2011). Prospek Pengembangan Cempaka di Sulawesi Utara (Jurnal Ilmiah). Badan Penelitian dan Pengembangan Kehutanan, Balai Penelitian Kehutanan Manado.

Kinho, J. dan Arif, I. (2011). Studi Keragaman Jenis Cempaka Berdasarkan Karakteristik Morfologi di Sulawesi Utara (Jurnal Penelitian). Balai Penelitian Kehutanan Manado.

Kurniawan, W. (2008). Analisis Pengendalian Persediaan Bahan Baku di Perusahaan Kecap Segitiga Majalengka. Program Sarjana Ekstensi Manajemen Agribisnis, Fakultas Pertanian, Institut Pertanian Bogor.

Nasutioon, A. H. (2003). Perencanaan dan Pengendalian Produksi. Edisi Pertama. Surabaya : 
Guna Widya.

Prawirosentono, S. (2007). Manajemen Operasi (operations management) analisis dan studi kasus. Edisi keempat, cetakan pertama. Bumi Aksara : Jakarta.

Prihasdi, R.D. (2012). Efisiensi Metode Economical Order Quantity (EOQ) dalam Pengambilan Keputusan Pembelian Bahan Baku dan Pengaruhnya Terhadap Total Biaya Pembelian pada PT. Amitex (Amanah Mitra Industri) Buaran Kabupaten Pekalongan. Skripsi. Fakultas Ekonomika dan Bisnis Universitas Diponegoro Semarang.

Ruauw, E. (2011). Pengendalian persediaan bahan baku(Contoh Pengendalian pada usaha Grenda Bakery Lianli (Jurnal). Manado.

Grenda Bakery Lianli Bahu Malalayang Universitas Sam Ratulangi, Fakultas Pertanian Manado. Skripsi

Sitorus, O. R. (2009). Jenis dan harga kayu komersial serta produk kayu olahan pada indutri kayu sekunder Panglong di kota Medan. Skripsi. Departemen Kehutanan Universitas Sumatera Utara Fakultas Pertanian, Medan.

Sutrisno. (2001). Manajemen Keuangan. Yogyakarta: Ekonisia 